\title{
A Study on the Improvement of Property Tax System of China under the Reconstruction of Local Tax System
}

\author{
Xiuli Wang \\ School of Economics and Management, Hubei Automotive Industries Institute, Shiyan, \\ 442002, China
}

\begin{abstract}
Keywords: Property Tax System; Existing Problems; Countermeasures; Improvement of Property Tax System
\end{abstract}

Abstract. According to the overview of the existing property tax system in China, the problems in the
existing property tax system are described in this paper, and the countermeasures are also given in
order to improve the property tax system of China for a new round of reforms of the tax system.

\section{Introduction}

In this paper, the problems such as inaccurate functionality orientation, narrow levy scope, unreasonable tax method in the existing property tax system are described and the countermeasures including defining the steps of property tax reform and functionality orientation, scientifically designing the constituent elements of property tax, delegating corresponding power to the local governments and improving supporting measures by governments are suggested based on the analysis of the necessity of the improvement of property tax system and according to the current status of the existing property tax system.

In the 12th Five-Year plan, China has clearly demonstrated: "we shall speed up the overall idea of tax system reform, research and promote house property tax reform and improve property tax system; gradually improve the local tax system, and delegate proper tax administration power to the provincial governments to nurture local mainstay tax source under the unified tax administration." China's tax system is mainly composed of turnover tax, income tax and property tax. The business tax and property tax make up the majority of the local tax revenue, of which the former accounts for 40 per cent and the later 10 per cent. According to the calculation of the State Administration of Taxation, the local tax concessions will be over 100 billion Yuan after "Business Tax's Conversion to Value Added Tax". As a result, the improvement of the secondary property tax will be an important means for nurturing the mainstay of the local revenue source. With the local tax concessions, the local non-tax revenue growth of the first half of 2012 was fast, leading to the situation of "filling the tax shortage with money from other revenues". In a great number of areas, such money is still from land. Therefore it is imperative to reform property tax related to the real estate for the achievement of tax reform, especially that of the real estate industry, and the unified tax system. The tax system reform over the past decade focused on turnover tax and income tax with few changes in property tax. Therefore, the improvement of the property tax system is the inexorable requirement for a new round of reforms of the tax system, which will create the conditions for the central government and local tax authority and unified tax system in urban and rural areas.

\section{Overview of the existing property tax system in China}

\section{Status quo and evaluation of house property tax}

House property tax is a levy with the house property as object and collected from the owner of the property based on the tax value or the rental income of the house property. The house property tax is collected from the domestic and foreign-funded enterprises and individuals since January 1, 2009. In recent years, with the stubbornly high house price, the property tax reform, which is regarded as the most powerful weapon of house price regulation, has been in the firing line. At present, the central government has clearly demonstrated the main idea of accelerating the pilot project of house property 
tax reform and then expanding gradually to the whole of China, and house property tax reform program was launched in Chongqing and Shanghai in 2011.

In the Chongqing program, it levies on two categories: 1, stock house, including the single-family house owned by individual and the second or above ordinary house recently acquired by the individual without registered permanent residence or business or job occupation in Chongqing; 2, incremental house, including the upscale house recently acquired by individual. Tax rates: 0.5 per cent for the single-family house and upscale house at the price which is below three times of the new commercial housing in the nine districts of the city over the last two years; 1 per cent for those between three times (including three times) and four times; $1.2 \%$ for those over four times (including four time) and $0.5 \%$ for the second or above ordinary house recently acquired by the individual without registered permanent residence or business or job occupation in Chongqing. From above we can conclude that Chongqing house property tax reform is designed primarily to limit upscale commercial house and counter real speculative activities, embodying the functionality orientation of adjusting the gap between the rich and the poor and optimizing the allocation of resources.

In the Shanghai program, it levies on the second or above house (stock house or incremental house) recently acquired by Shanghai resident and the house recently acquired by non-Shanghai resident. The tax shall be calculated based on the assessed value of the taxable house determined according to the real estate market price and the specified cycle. At the initial stage of pilot project, the tax shall be temporarily calculated based on 70 per cent of the transaction price and levied at the rate of 0.6 per cent. The rate of $0.4 \%$ is for the taxable house of which the transaction price is lower than twice (including twice) of the average price of the new commercial house built in the prior year. Provided the gross family housing area (floor area) per capita of the Shanghai resident who recently acquired the second or above house is not more than 60 square meters (i.e. tax-exempt housing area, including 60 square meters), his recently acquired house is exempt from the house property tax; provided the per capita area is over 60 square meters, the house property tax shall be calculated and levied on the exceeding part of the new house according to the provisions. From above we can conclude that Shanghai house property tax reform is designed primarily to counter real estate speculative activities, embodying the functionality orientation of optimizing the allocation of resources and adjusting the gap between the rich and the poor.

After more than a year of practice, it is worth approving that the specific measures for administration of property tax collection have been stipulated by the pilot provincial and municipal governments based on the practical situation, which means that the central government has delegated corresponding power of collection and administration to the local governments. However, the actual collection result of "A few houses are taxed in Shanghai and a little money is collected in Chongqing" is of little symbolic significance for the house property tax reform. And of course, it is difficult to verify the occupied house units and areas of resident because the reform in the two cities is at the early pilot stage and there is no interconnection between the housing systems in various regions. At present, the tax is levied on a few stock houses and new houses. There are a larger number of actual obstacles and many specific problems to be addressed in the full implementation in the two cities and the promotion in whole China.

\section{Status quo and evaluation of vehicle and vessel tax}

Vehicle and vessel tax is a levy with the vehicle and vessel as object and collected from the units and individuals who own vehicle or vessel. In recent years, after two major reforms in 2006 and 2011, the changes in the current vehicle and vessel tax law are as following: 1 , the taxation basis for passenger service vehicle has been changed from seating capacity to displacement; 2 , tax concessions for the cars with the displacement under $1.6 \mathrm{~L}$; 3, addition of tax concession for new energy vehicles, 4, incorporation of public opinion in legislation to making the scientific and democratic legislative examples. Although this reform appear to be conforming to the conditions in China for it is conducive to energy-saving and emission-reduction without laying increased tax burden on the public, in fact it focuses on the adjustment of the development of vehicle industry and the vehicle consumption of residents. Taking the essence of property tax into account, there are major problems of the reform: firstly, the functionality orientation of adjusting the gap between the rich and the poor resulted from 
the income inequality has not embodied; secondly, the vehicle and vessel tax reeks with repetition although it is levied on the basis of different exhaust emissions, because the consumption tax, vehicle purchase tax and fuel consumption tax have been levied and the purpose of energy-saving and emission-reduction has been realized by the adjustment of the consumption structure in the vehicle market and the support for the vehicles with small displacement. Thirdly, it is levied based on the displacement, which is internationally levied on value of the property. Fourthly, with low revenue, it is of small contribution to the local finance.

\section{Problems with the existing property tax system in China}

\section{Inaccurate functionality orientation of property tax}

The above status quo shows that the property tax has the functionality of raising financial revenue, adjusting the gap between the rich and the poor and optimizing the allocation of resources. According to the house property tax reform pilots of Shanghai and Chongqing, its orientation is embodied in the later two functionalities and the functionality of raising financial revenue has not been achieved. The inaccurate functionality orientation leads to the deviation in determining taxpayer, tax object, basis of tax assessment and tax rate from the essential characteristic of property tax.

\section{Narrow levy scope of property tax}

Not to mention whether the property tax covers the death tax, inheritance tax or real estate tax, viewing from the objects of the existing vehicle and vessel tax and house property tax alone, the actual levy scope is narrow. Taking the house property tax as an example, the geographical levy scope is limited to cities, counties, townships and mining areas, but excluding rural areas, causing the different treatment of house property tax in urban and rural areas. As a result, many peri-urban peasants live on rent. They have a fine income without paying house property tax. In terms of levy scope, the object of house property tax is merely limited to house without covering other kinds of real estates, which may lead to the loss of tax source and harmful influence to the equity of tax burden. Furthermore, the tax-exemption policies for owner-occupied housing also cause the loss of tax source and harmful influence to the equity of tax burden.

\section{Unreasonable tax method}

The tax method of the existing house property tax: for owner-occupied housing, 1.2 per cent per year on the basis of its original value minus 10 per cent to 30 per cent of depreciation; for the rental housing: 12 per cent per year on the basis of its rental income. There are three problems in above tax method: firstly, the value of owner-occupied housing contains not only the value of itself but also the prices of land-use right. It inevitably leads to double taxation because the tax of land-use right has been levied via the land-use tax of cities and towns. Secondly, the difference of the basis of tax assessment between the two categories of houses causes the imbalance of tax burden. It is reflected in the following: the original value of house is calculated based on the historical cost and the rent on the current market price, which will result a large difference in tax amount due to the incomparability of their calculation basis, especially for the house with a long history and the uncertainty of the usage. Thirdly, the basis of tax assessment of rental income provides taxpayers with opportunity for tax avoidance and tax evasion. Because the rent, which is determined by the contractual parties via the negotiation when entering into a tenancy contract, lacks objective and fair judging criteria, the rent is liable to be manipulated.

There are many problems in vehicle and vessel tax and its tax method as well.The adjustment of vehicle and vessel tax rate in accordance with the displacement is more likely to be an inheritance of the original regulations and a compromise of stakeholders. For example, there is a great increase in the tax on the vehicles with large displacement. 5400 Yuan of tax on the vehicles with 4.0 liters or above of displacement, which are generally valued at one million yuan, has no practical significance in the adjustment of consumption propensity, because the owners can afford such amount of tax with ease. In addition, the new law does not favor the vehicles with small displacement: the tax on those with 1.0 liters (included) or less is untouched; 16 per cent of decrease for $1.0 \sim 1.6$ liters; 50 per cent of 
decrease for 1.6 2.0 liters; 30 per cent of decrease for $2.0 \sim 2.5$ liters, over 20 per cent of decrease for 2.5 to 3.0 liters, and high tax rate for 3.0 liter (included) or above.

Integrating the roles of house and vehicle and vessel in a family, the most important property of a family is house which is always worth over 1 million or 10 million or even 100 million. The state, however, handles the house property tax reformgingerly. Although it is operated with the consideration of many other non-property factors, it is unreasonable to consider and discuss the tax on vehicle, a median- and low-end consumption goods, but no tax is levied on house, the most important property of a family. Moreover, vehicles are varied in price from 30,000 to several million Yuan, and their values continuously depreciate; furthermore, it transgresses the essence of property tax to levy on a vehicle based on its displacement rather than its value, although from the perspective of new vehicle values, there is a proportional relationship between the value and the size of replacement.

\section{Other problems}

Firstly, with relatively small proportion, property tax does not enjoy a high position in China's tax system; secondly, it is adverse to fairness due to its chaotic tax concession scope and tax avoidance space. The wide and indiscriminate tax concession scope of the exiting tax system has exactly reduced the tax scope and lowered tax base, weakening the role of taxation and increasing the unfairness of tax burden. Thirdly, the limited jurisdiction of the local governments is not conducive to motivating the levy and management of the local governments and tax authorities.

\section{Countermeasures for the improvement of property tax system in China}

\section{Defining the steps of property tax reform and functionality orientation}

The property tax system reform can not be accomplished in a day. Making a comprehensive survey of the world history of the property tax system reform, we can see that the developed countries have undergone a long historical process. From the perspective of the sequence of taxation forms of property tax, with the property taxes of different names on the real estate in the early days and the generally levied death tax, donation tax and net-worth tax in the modern time, the property tax has become multiple from single and is developing from simple and crude to sound and complete. In addition, judging from international experience, property tax is the main source of revenue of the local governments and the stable revenue is propitious to the reasonable budget of the local governments. I believe that property tax will be the main tax category thanks to its characteristics for the following 3 reasons: firstly, China has large stock of real estates and inventory of vehicles and vessels and it is difficult to shift tax burden, so they can be the growing source of revenue for the local governments. Secondly, due to the strong territoriality of the tax objects of house and vehicle and vessel, it is difficult to supervise them for the central government, and the tax is preferred to be collected by the local governments to arouse their initiative. Thirdly, theoretically speaking, property tax is favorable and of high correspondence. By serving local economy with high financial transparency without increase of prices, it helps appease the hostility to tax. In summary, China's property tax system should have the main function of raising local revenues and the secondary function of adjusting the gap between the rich and the poor and allocation of resources.

\section{Scientifically designing the constituent elements of property tax}

The specific measures includes: firstly, reforming and improving house property tax; levying based on the market value of house; taking the hierarchically proportional tax rate; expanding the levy scope of property tax by bringing the owner-occupied housing into the levy scope, and a threshold may set at the transition period. Secondly, it is recommended to levy vehicle and vessel tax based on its value. Thirdly, converting the fixed tax rate to proportional tax rate. Fourthly, levying death tax and donation tax.

\section{Delegating corresponding power to the local governments}

There are three methods for local tax legislation in the countries that implement tax distribution system: 1 , the local governments obey the central legislation; 2 , with the categories of taxes set by the 
central government, the local governments have the power to determine the initiation or cessation of tax and the specific tax rate; 3, under the authorization of the central government, the local governments can levy new tax. At present, China mainly adopted the first method and it can make the transition to the second one, so that the different situations of taxpayers can be taken into account to make regional tax abatement policies to reasonably set the threshold, exemption, and pre-tax deduction item, and to strength the suitability of taxation policies for the local economy.

\section{Improving supporting measures by governments}

The improvement of property tax system also requires the supporting measures made by governments, such as personal credit information system construction, property registration and assessment system, strengthening of tax data information building, speeding up the establishment of authoritative and equitable professional assessment institutions, training of professional assessment personnel, solution of the problems of difficult levying, the sustainable development of local finance and equalization of basic public services, etc. In addition, local tax authorities shall carry out operational training and extensive propaganda to increase the transparency of property tax levy to make all citizens recognize and understand property tax and appease the hostility and abomination to tax.

\section{References}

[1] Shi Junguo: Reflection on the Property Tax Reform in China. Knowledge Economy. Aug. 2012

[2] Liu Zhicai: About How to Improve China's Property Tax Structure. China Finance and Economic Review. Feb. 2012

[3] Wang Tao and Zhu Wei: House Property Tax in Chongqing Has not Yielded Conspicuous Results 7 months after Implementation and Expanding, Levy Scope is Proposed. Economic Information Daily. Sep. 07, 2011

[4] Hao Linlin: On the Function of Property Tax in China. Special Zone Economy. Apr. 2010

[5] Qiao Ye: On the Enlightenment of US Property Tax System Upon China. Sichuan Provincial Conditions, May. 2008 